\title{
NOTES ON STARFISH ON AN ESSEX OYSTER BED
}

\author{
By D. A. Hancock \\ Fisheries Laboratory, Burnham-on-Crouch
}

(Text-figs. I-9)

In a previous paper (Hancock, I955) an account was given of the feeding behaviour of the starfish Asterias rubens L. and the common sunstar Solaster papposus (L.) on Essex oyster beds. In discussion, it was stated that there was no evidence that, in the conditions described, a cultivated oyster ground provided a greater attraction than an uncultivated one. The present work was undertaken to provide information on this subject, and also on the movements, growth and ecological relationships of starfish. Further experiments were made on feeding behaviour, particularly of the young starfish.

Samples required to give information on the growth and distribution of starfish were obtained from regular surveys of an oyster bed, by a series of parallel dredge hauls covering both cultivated and derelict bottoms. In November 1954, a section of oyster ground, $125 \mathrm{~m}$ wide, and stretching from one bank to the other(Fig. I), was marked out at the Southward Laying, River Crouch. The first dredge haul was made with two $4 \mathrm{ft}$. 6 in. dredges over the $125 \mathrm{~m}$ width, parallel to the edge of the north shore at L.W.O.S.T. and Io $\mathrm{m}$ from it. Buoys were used to mark distances offshore, and subsequent dredge hauls were made parallel with each other $20 \mathrm{~m}$ apart, and, when time permitted, were continued as far as the south shore, giving a total of twenty-six stations. This procedure was repeated approximately monthly. The survey dates were chosen with tides of about the same height.

\section{DESCRIPTION OF THE BOTTOM}

At the Southward Laying, an area below L.W.O.S.T. is fully cultivated; most of the slipper limpets (Crepidula) have been removed and oysters have been relaid. Farther offshore the ground becomes semi-derelict with more Crepidula, and towards midstream is covered by an almost pure population of Crepidula (Table I, Stations 6-II). In mid-river there is a submerged bank shallowest at Station I6 (Fig. 2) where, although little cultivation is done, tidal scour has made the bottom less muddy, and there is plenty of shell with large quantities of 'ross' or Sabellaria. There are some oysters, and, although Crepidula is present, the bottom is very much cleaner than in the deeper water over stations 6-II. The nature of the bottom at each dredge station is given in Table I. 


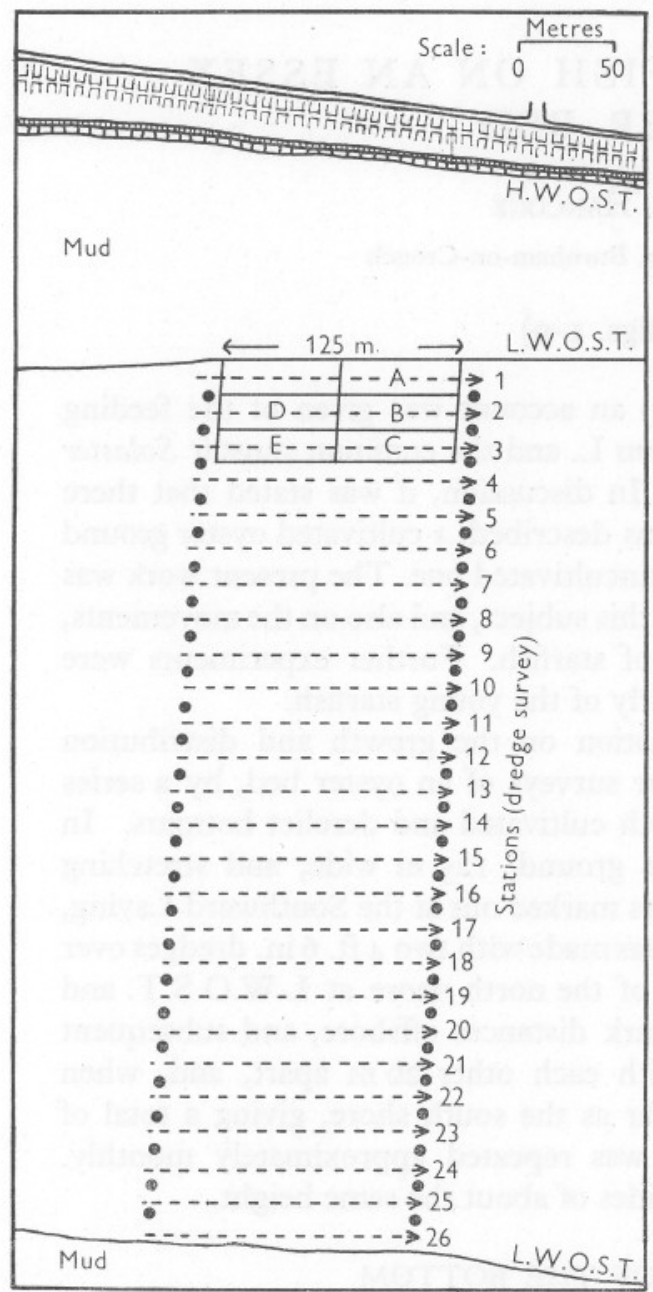

Results of grab survey

(Showing numbers of Asterias in approx. position of grab hauls)

I. Stations A E: 10 grabs per station

\begin{tabular}{|ccccc|ccccc|}
\hline & & & & 2 & 2 & 4 & 12 & 0 \\
4 & 2 & 3 & 2 & 2 & 1 & 1 & 3 & 1 & 3 \\
\hline 2 & 0 & 2 & 1 & 1 & 4 & 3 & 3 & 5 & 3 \\
\hline 2 & 9 & 1 & 8 & 3 & 6 & 7 & 4 & 9 & 15 \\
0 & 5 & 4 & 5 & 6 & 7 & 8 & 1 & 0 & 2 \\
\hline
\end{tabular}

II. Stations D B (repeat): 5 grabs per station

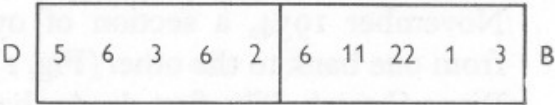

Fig. I. Map showing part of the Southward Laying, River Crouch used for dredge surveys, recapture experiment and grab sampling. Dotted lines show positions of parallel dredge hauls $\mathrm{I}-26$ between buoys ( ). Enclosed rectangles (A-E) show areas surveyed by grab sampler. Areas B and D (dredge Station 2) were also used for the recapture experiment (see text). The results of the grab survey are also shown diagrammatically.

\section{DISTRIBUTION OF ADULT STARFISH}

From the results of the surveys the distribution of Asterias and Solaster was plotted (Fig. 2). Figures for bottom animals taken in dredges should be compared with caution because a dredge is not a fully reliable sampler (Shelbourne, 1957). However, the regular appearance of concentrations of 
particular animals on certain sections of the river suggests that in this instance, the dredge gave a satisfactory distribution picture.

It was shown previously (Hancock, I955) that during 1954 the largest numbers of adult Asterias were taken from stations 3-6 (50-1 Io m below L.W.O.S.T., Fig. 2). Later, during 1955 and in 1956 , the main area of abundance shifted offshore, perhaps as a result of the removal by dredging

TABLE 1. SOUTHWARD LAYING, RIVER CROUCH. NATURE OF BOTTOM SHOWN BY DREDGING ON STATIONS 1-26.

\begin{tabular}{|c|c|c|}
\hline \multirow[b]{2}{*}{ Station } & \multicolumn{2}{|c|}{ Nature of bottom } \\
\hline & 1955 & 1956 \\
\hline $\mathbf{I}$ & Shell, oysters, few Crepidula & Shell, oysters, very few Crepidula \\
\hline 2 & Shell, oysters, few Crepidula & Shell, oysters, very few Crepidula \\
\hline 3 & Shell, oysters, Crepidula & Shell, oysters, very few Crepidula \\
\hline 4 & Shell, Crepidula, some oysters & Shell, oysters, few Crepidula \\
\hline 5 & Shell, Crepidula & Shell, Crepidula, oysters \\
\hline 6 & Shell, many Crepidula, muddy & Shell, Crepidula, oysters \\
\hline 7 & Shell, many Crepidula, muddy & Shell, Crepidula, muddy \\
\hline 8 & Shell, many Crepidula, muddy & Shell, Crepidula, muddy \\
\hline 9 & Shell, Crepidula & As 1955 \\
\hline Io & Shell, Crepidula & As 1955 \\
\hline II & Shell, Crepidula & As 1955 \\
\hline I2 & Shell, Sabellaria, Crepidula, some oysters & As 1955 \\
\hline I3 & Shell, Sabellaria, few Crepidula and oysters & As 1955 \\
\hline 14 & Shell, Sabellaria, few Crepidula and oysters & As 1955 \\
\hline 15 & Shell, Sabellaria, few Crepidula and oysters & As 1955 \\
\hline 16 & Shell, Sabellaria, few Crepidula and oysters & As 1955 \\
\hline I7 & Shell, Sabellaria, few Crepidula and oysters & As 1955 \\
\hline I8 & Shell, Sabellaria, few Crepidula and oysters & As 1955 \\
\hline 19 & Shell, Sabellaria, few Crepidula and oysters & As 1955 \\
\hline 20 & Shell, Sabellaria, few Crepidula and oysters & As I 955 \\
\hline $2 I$ & Shell, Sabellaria, few Crepidula and oysters & As 1955 \\
\hline 22 & Clean shell, Sabellaria, few oysters & As 1955 \\
\hline 23 & Shell, Sabellaria, some stones & As 1955 \\
\hline 24 & Shell, Sabellaria, stones and mud & As 1955 \\
\hline 25 & Shell, Sabellaria, stones and mud & As 1955 \\
\hline 26 & Hard mud and boulders, some shell & As 1955 \\
\hline
\end{tabular}

of large numbers of Crepidula, close to the cultivated ground, causing the Asterias to seek more abundant food farther offshore. No evidence was obtained of extensive migrations, and, particularly, there was no mass movement of adult Asterias to the cultivated oyster ground inshore just below L.W.O.S.T. The population was maintained just offshore in association with large numbers of Crepidula.

Solaster, however, had quite a different distribution and there was little overlapping between the adult populations of Asterias and Solaster (Fig. 2). The largest numbers of adult Solaster occurred throughout the year on grounds commencing $\mathrm{I} 80 \mathrm{~m}$ from the north shore (Station Io onwards) and extending to the opposite shore. They were not associated with the cultivated oyster ground near the north shore, nor with the main Crepidula zone (Stations 6-II). Solaster was mainly found on the submerged bank (Fig. I), where 


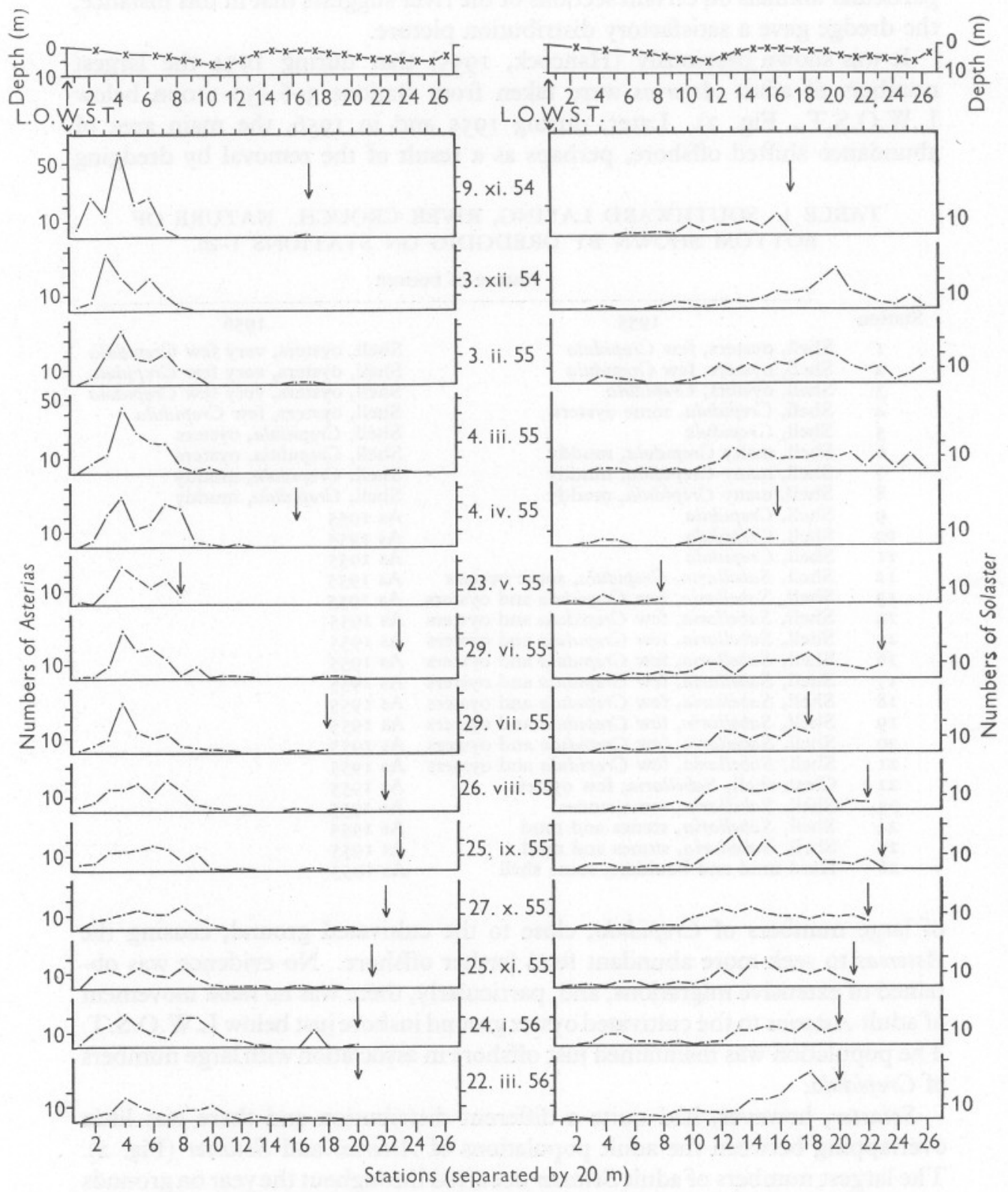

Fig. 2. Numbers of adult Asterias and Solaster taken using two $4 \mathrm{ft}$. 6 in. power dredges in parallel dredge hauls across the River Crouch at the Southward Laying 1954-56, commencing Io $\mathrm{m}$ from L.W.O.S.T. on the north shore. Sections across the river showing mean depths are given. The final dredge station on each date is indicated by an arrow. 
the bottom was of 'ross' (Sabellaria), some Crepidula and oysters, with Alcyonidium, Sertularia, Dendrodoa and some barnacles. The type of bottom at each station is shown in Table $\mathrm{I}$.

\section{DISTRIBUTION AND SETTING OF YOUNG STARFISH}

Juvenile Asterias were taken in 1955, for the first time, on 29 July, when they were $\mathrm{I}-7 \mathrm{~mm}$ in maximum radius (Figs. 3,5 and 6). By 'maximum radius' is meant the length of the largest arm from its tip to the centre of the mouth. The distribution of juveniles on the stations at the Southward Laying was compared at first by counting the population on fifty oyster shells taken at random from the dredge hauls on each station. On 29 July the largest numbers were taken on stations 2 and 3 , with little settlement offshore (Fig. 3). Further settlement had occurred by 26 August when numbers had increased on all stations, but particularly offshore. When sampled on 25 November the juveniles had grown so much (Fig. 5) that they became easily detached from shells in the dredges, and the numbers on shells could no longer be used for comparison. On this and subsequent dates, the density of young starfish was estimated by subsampling the dredge contents, and calculating the numbers in two full dredges. These numbers could be compared more easily with the numbers of adult starfish (Fig. 2). Most juveniles continued to be found on inshore stations, with a fairly large settlement on Stations I2-20.

Juvenile Solaster appeared earlier in the year than Asterias, on 23 May 1955. This was expected, as in the laboratory Solaster spawned from 25 to 27 February 1954 at a mean temperature of $9^{\circ} \mathrm{C}$, and on 16 March 1955 when the temperature was again $9^{\circ}$ C. Asterias, however, did not spawn in 1954 until 29 May, when the temperature had reached $15^{\circ} \mathrm{C}$. Solaster eggs spawned on 25 February 1954, kept under observation in the laboratory, were floating orange spheres $0.9 \mathrm{~mm}$ in diameter. By 2 March they had become gastrulae, which elongated in a day or two, and by ro March had developed three larval arms (as figured by Gemmill, 1912, for Solaster endeca, and by Chadwick, I9I4). Metamorphosed stages, less than I $\mathrm{mm}$ in diameter, with the first tube feet, were found attached to the bottom of the tank early in April. Solaster eggs were taken in the plankton from the River Crouch in 1956 for the first time on 26 March. The distribution of young Solaster at the Southward Laying was very similar to that of the adults, the greatest settlement being consistently about $250 \mathrm{~m}$ from the north shore (Fig. 3, Stations II-I4).

The numbers of Asterias settling in 1955 were much greater than those of Solaster. The greatest quantity taken during the year in two full dredges was 2724 on Station 2 on 23 September. The corresponding total for Solaster was 42 taken on Station II on 27 October 1955. In 1956, no settlement of Asterias was observed. Small numbers of Solaster settled, but they were not seen until 4 June, when they were considerably smaller than the previous year group was in June 1955 . 


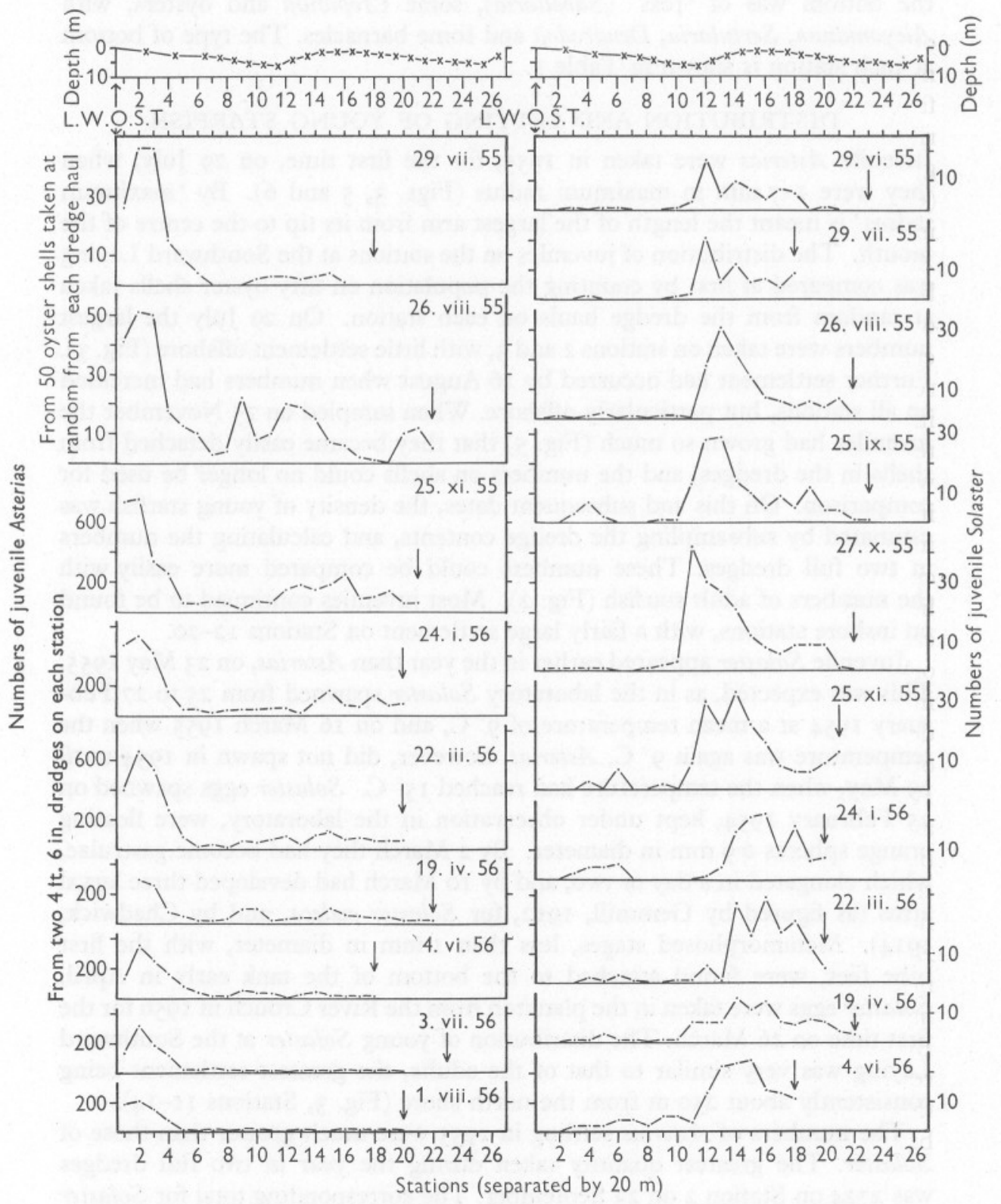

Fig. 3. Numbers of juvenile Asterias and Solaster taken using two $4 \mathrm{ft}$. 6 in. power dredges in parallel dredge hauls across the River Crouch at the Southward Laying 1955-56, commencing Io $\mathrm{m}$ from L.w.o.s.T. on the north shore. On 29 July and 26 August 1955 Asterias were counted from only 50 shells in each dredge haul. From 25 November onwards, the total number in each dredge haul has been represented. Sections across the river showing mean depths are given. The final dredge station on each date is indicated by an arrow. 
There was in 1955 , therefore, considerably more overlapping of the juveniles of the two starfishes than of the adult populations. Young Asterias settled in maximum density inshore on cultivated oyster ground, but settling also occurred farther offshore in the Solaster zone. Young Solaster settled mainly in midriver in the region of greatest abundance of adults, suggesting perhaps a gregariousness of settling near the parents as in certain other invertebrates (Cole \& Knight-Jones, I949, in oysters; Knight-Jones \& Stevenson, I950, in Elminius). Both young and adult Solaster have been observed devouring Asterias, particularly juveniles, and this, coupled with the discrete settling behaviour of Solaster, is believed to be responsible for the no more than slight overlapping of the two adult populations. Asterias is capable in a lesser capacity, of devouring young Solaster. Although there was such an enormous settlement of Asterias on the Southward Laying in 1955, the numbers taken in dredge hauls decreased steadily-from over 2700 on Station 2 on 23 September 1955 to only 44 on 15 October 1956 . The distribution at the Southward Laying showed that this decrease was occurring on all stations, that is, it was not due to an inshore or offshore movement. A certain amount of migration of juveniles to neighbouring grounds might have occurred, but conditions there were no different from the Southward Laying. It is believed that the great decrease in the numbers was due to a heavy mortality caused by competition and cannibalism, resulting from a prolonged shortage of natural food and predation by Solaster. Galtsoff \& Loosanoff (1939), in America, observed that an abundant set of Asterias forbesi Desor, greatly decreased within I month after settling, and suggested that cannibalism, observed frequently between young starfish in the laboratory, was responsible. It is significant that, before the settlement of young Asterias in 1955, shells and oysters at the Southward Laying were densely covered by barnacles, but by the end of August 1955 it was impossible to find a live barnacle there. Until the end of 1956, although barnacle settlement was elsewhere normal, the Southward Laying was still free. It is believed that the juvenile Asterias devoured the barnacles, giving them no chance to grow to recognizable size. The absence of freshly settled stages of Asterias in 1956 may have been a direct consequence of the lack of young barnacles required as food. By mid-1956, the distribution of the young of the two species of starfish resembled that of the adult populations (Figs. 2, 3). It is interesting to note that following the reduction of the numbers of Asterias to a normal level, barnacles reappeared in large numbers on the Southward Laying in 1957.

\section{POPULATION DENSITY}

Two methods were employed to estimate the density of young Asterias on the Southward Laying. These had been used previously with some success for determining the population density of Urosalpinx (Hancock, in press), and 
comprised $(a)$ marking and recapture experiments, and $(b)$ a survey using a $\frac{1}{10} \mathrm{~m}^{2}$ van Veen grab. Loosanoff (1937, 1953) described the marking of starfishes from the Atlantic coast of America with Nile Blue Sulphate, and Vernon (1937) used Neutral Red. Feder (1955) used both these methods with success on Pacific coast starfishes, and found that plastic disc tags attached by stainless steel were useful, but very liable to cause injury or loss of the tagged arms. No doubt the proportion surviving uninjured would be useful in migration or growth studies, but the method would be less reliable for recapture data.

Employing method $(a)$, an area of oyster ground $20 \mathrm{~m}$ wide was marked out with buoys, its inner edge being parallel to, and $20 \mathrm{~m}$ below, the shore at L.w.o.s.T. on the Southward Laying (Fig. I, area D-B). Dredge hauls were made on this area on 23 September 1955, parallel to the shore, and Iooo young Asterias were marked and returned, to be searched for by subsequent dredging. Marking was done by diluting a stock solution of Nile Blue Sulphate about ten times with sea water. This was sufficient to dye a large number of Asterias immersed in it in 5-10 min. The normal reddish brown of the aboral surface became darker and bluish-green in colour. The blue coloration showed up most clearly on the parts normally white, such as the surface of spines, and the oral surface. The blue stain of Nile Blue Sulphate was retained by marked starfish until at least to months after marking. A series of young and old dyed Asterias were retained in tanks in the laboratory for several months with no significant mortality.

Young Asterias were capable of quite rapid movement and for this reason only an hour or two was allowed for mixing with the normal population before redredging. Dredging, marking and redredging was continued on I2 and I4 October. The first group marked on 23 September totalled 1000, and on I2 October a second group of I 450 and a final group of 2165 were dyed making a total of 46I5. Bailey's (195I) modification of the 'Lincoln Index' was applied to the numbers recaptured on each date. This is: $\breve{x}=a(n+\mathrm{I}) /(r+\mathrm{I})$, where $\check{x}$ is the total population in the marked area, $a$ is the number of individuals marked, $n$ is the size of a random sample containing $r$ marked individuals. The total number of recaptured starfish was 365 , compared with 16,903 unmarked. From calculations based on marking of the three groups (Table 2), the average figure for young Asterias per $\mathrm{m}^{2}$ over the total area of $2500 \mathrm{~m}^{2}$ used for recaptures was found to be I3I. Uneven distribution of marked starfish over the area may account for the large variation between 28 and 296 per $\mathrm{m}^{2}$ shown in Table 2.

The sorting of several thousand small starfish from the contents of a dredge is tedious and lengthy, and it was felt that a grab survey might be more accurate and would take less time. Grabbing could not be done until a month later, on Io November, so that the results cannot be compared strictly with those from the recapture experiment described above. An area of oyster ground below L.W.o.s.T. was divided up with buoys to include the area used in the 
recapture experiment (Fig. I). Ten grab hauls $\left(\frac{1}{10} \mathrm{~m}^{2}\right)$ were made at random in each subarea (Fig. I, A-E), so that their total represents the density per square metre for each station. The results showed great variation between single grab samples, from 0-I5 on one station (Fig. I, C). The bottom deposits were found to be variable, and the absence of Asterias could usually be related to clay or mud with no shells. A maximum of 59 per $\mathrm{m}^{2}$ was found on Station C, with an average of 37 per $\mathrm{m}^{2}$ for the whole area. Station D had $\mathrm{I}$, and Station B, 27 starfish per $\mathrm{m}^{2}$, giving an average of 23 for the area D-B used in the recapture experiment.

The mid-level area D-B (Fig. I) used for the recapture experiment was re-examined by a further Io grab hauls intended to confirm the original results (Fig. I). This time, however a total of 65 starfish per $\mathrm{m}^{2}$ was obtained, compared with the previous average of 23 per $\mathrm{m}^{2}$. The variation from $\mathrm{I}$ to 22 in individual grab hauls (Fig. I) again emphasizes the patchiness of Asterias, and shows that a much larger number of grab hauls would be required to give more significant results.

TABLE 2. RECAPTURES OF MARKED ASTERIAS FROM DREDGE HAULS OVER STATION 2 (D-B)

(Each haul with two 4 ft. 6 in. dredges.)

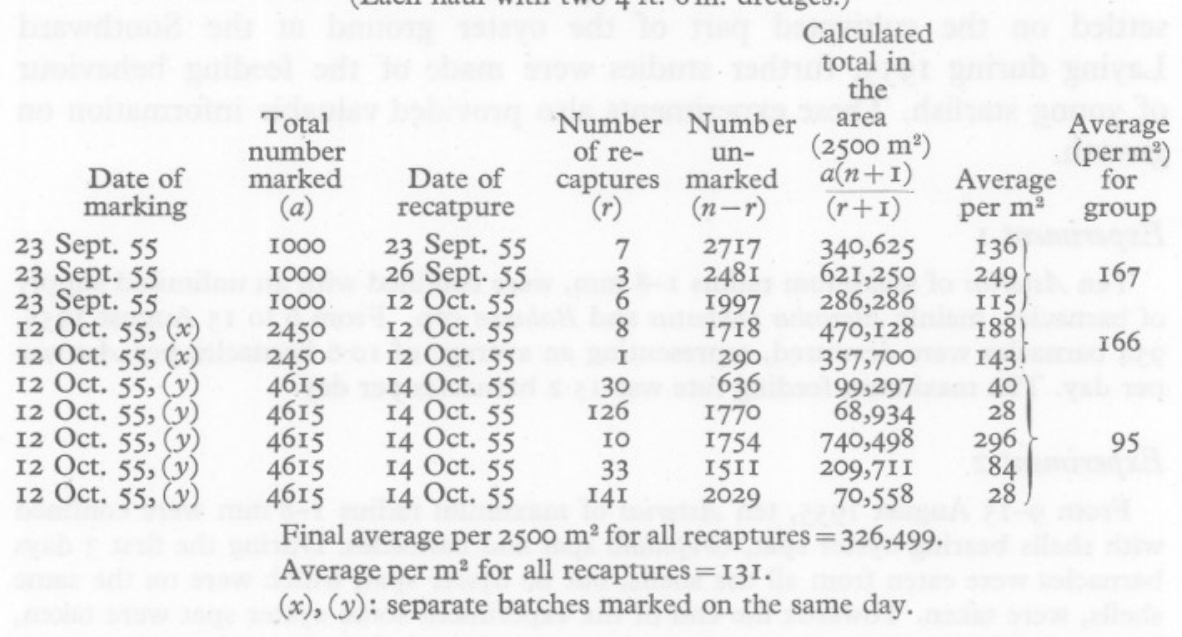

The figure of 37 per $\mathrm{m}^{2}$, representing the average of the two series of grab hauls on Stations D-B, differs substantially from that of 131 obtained from recapture data from the same area, but it must be remembered that grab sampling was delayed for one month. Dredge survey results (Fig. 3) indicated that the density of young Asterias over the whole Southward Laying area was decreasing during this period; on 25 November 1955, for example, less than 800 were obtained per haul with two dredges on Station 2 (Fig. I, over D-B) compared with the usual catch of nearly 2000 before the recapture 
experiment. The largest number obtained in two $4 \mathrm{ft} .6$ in. wide dredges dragged over $125 \mathrm{~m}$ on the same area was 2724 on 23 September 1955 on Station 2, which, when related to the area covered by the dredges, represents only 8 per $\mathrm{m}^{2}$, and demonstrates the low efficiency of dredges for catching small starfish.

It is evident that, by either method, the estimation of density of a large population with such irregular distribution, even over a small area, can be based with confidence only on intensive sampling.

\section{FEEDING}

\section{LABORATORY EXPERIMENTS}

It was demonstrated in laboratory experiments (Hancock, 1955) that, although Asterias occasionally ate spat and adult oysters, the greater part of its food was composed of animals in competition with the oyster. The smaller sizes of Asterias ate large numbers of barnacles, with occasional spat of oysters and Crepidula. The larger ones occasionally ate oysters and oyster spat, but almost always exhibited a preference for mussels, and, in the absence of these, for Crepidula, and sometimes even for Urosalpinx.

To assess the effects of the very large number of juvenile Asterias which settled on the cultivated part of the oyster ground at the Southward Laying during I955, further studies were made of the feeding behaviour of young starfish. These experiments also provided valuable information on growth.

\section{Experiment I}

Ten Asterias of maximum radius I-8 mm, were confined with an unlimited supply of barnacles, mainly Elminius modestus and Balanus spp. From 6 to I5 August 1955, 954 barnacles were devoured, representing an average of 10.6 barnacles per Asterias per day. The maximum feeding rate was 15.2 barnacles per day.

\section{Experiment 2}

From 9-15 August 1955, ten Asterias of maximum radius I-8 mm were confined with shells bearing oyster spat, Crepidula spat and barnacles. During the first 3 days barnacles were eaten from all the shells, but no oyster spat, which were on the same shells, were taken. Towards the end of the experiment some oyster spat were taken, but nearly all of the barnacles had been destroyed. A total of 582 barnacles and I I oyster spat ( 6 of $2 \mathrm{~mm}, 4$ of $3 \mathrm{~mm}$, and I of $7 \mathrm{~mm}$ average diameter), but no Crepidula spat, were eaten in 6 days. The Asterias finally measured 3.7-10.9 mm.

\section{Experiment 3}

Thirty Asterias, I2-13 mm max. radius, were isolated with Crepidula spat. In 7 days, IO-17 September 1955, only 5 Crepidula (7-9 $\mathrm{mm}$ in length) were eaten. When ten of these Asterias were transferred to a tank containing mussel spat, these were attacked immediately and the feeding rate greatly increased. The remaining 20 Asterias were retained with Crepidula spat, but the feeding rate continued to be low. From 
Io September to I9 November 1955, only 26 Crepidula spat (4-13 mm in length) were eaten. The Asterias finally measured $8-12 \mathrm{~mm}$. Only fourteen of the Asterias remained on I9 November 1955, the others having been the victims of cannibalism.

\section{Experiment 4}

Twenty Asterias, I2-I3 mm, were isolated with oyster spat. Between ro September and 2 October 1955 , only 6 spat ( $4-8 \mathrm{~mm}$ diameter) were eaten. When barnacles were added on 12 October, the feeding rate increased, and, although 2566 barnacles were devoured between I2 October and 3I December 1955, no further oyster spat were taken. This experiment showed a maximum feeding rate of 5 barnacles per Asterias per day. The measurements of the Asterias were as follows:

$\begin{array}{ccc}\text { Date } & \begin{array}{c}\text { Maximum } \\ \text { radius } \\ (\mathrm{mm})\end{array} & \text { Food } \\ \text { (1955) } & \text { I2-13 } & - \\ \text { I0 Sept. } & 9-12 & \text { Oyster spat } \\ \text { I2 Oct. } & 9-14 & \text { Barnacles } \\ \text { 4 Nov. } & 9-19 & \text { Barnacles }\end{array}$

\section{Experiment 5}

I7 September 1955. Ten Asterias from Expt. 3 (I2-13 mm) were confined with many mussel spat. Initially the feeding rate was high, but, as the size range of the mussel spat increased through growth, they gradually became too large for small starfish to open, and, by the beginning of December, when the mussels were all about $20 \mathrm{~mm}$ in length, feeding virtually ceased. When the mussels were replaced with barnacles, however, a high feeding rate was resumed.

$\begin{array}{cccc}\text { Date (1955) } & \begin{array}{c}\text { Size range } \\ \text { of mussels } \\ \text { (mm) }\end{array} & \begin{array}{c}\text { Number } \\ \text { eaten by Io } \\ \text { Asterias }\end{array} & \begin{array}{c}\text { Number per } \\ \text { Asterias } \\ \text { per day }\end{array} \\ \text { I7-30 Sept. } & 3-10 & 165 & 1 \cdot 3 \\ \text { I-3I Oct. } & 2-15 & 269 & 0 \cdot 9 \\ \text { I-30 Nov. } & 3-24 & 84 & 0 \cdot 3 \\ \text { I-7 Dec. } & 20-23 & 3 & 0 \cdot 04 \\ \text { 7-3I Dec. } & \text { Barnacles } & 480 \text { barnacles } & 2 \text { barnacles }\end{array}$

The measurements of the starfish were as follows:

\begin{tabular}{lcl} 
Date (1955) & $\begin{array}{c}\text { Maximum radius } \\
(\mathrm{mm})\end{array}$ & \multicolumn{1}{c}{ Food } \\
I0-17 Sept. & 12-13 & Crepidula spat \\
I7 Sept.-12 Oct. & 10-17 & Mytilus spat \\
I2 Oct.-14 Nov. & 15-24 & Mytilus spat \\
I4 Nov.-31 Dec. & I6-29 & Mytilus spat and barnacles
\end{tabular}

\section{Experiment 6}

Eleven Asterias (all of maximum radius $20 \mathrm{~mm}$ ) were offered equal numbers of Crepidula and oyster spat. Between I January and 29 March 1956, 32 oyster spat and 42 Crepidula spat were eaten. By the end of March the range of maximum radius length had decreased from $20 \mathrm{~mm}$ to $8-16 \mathrm{~mm}$. Oyster spat eaten had a maximum diameter range of $8-25 \mathrm{~mm}$ and Crepidula $5-22 \mathrm{~mm}$. The growth of these starfish is discussed below. 


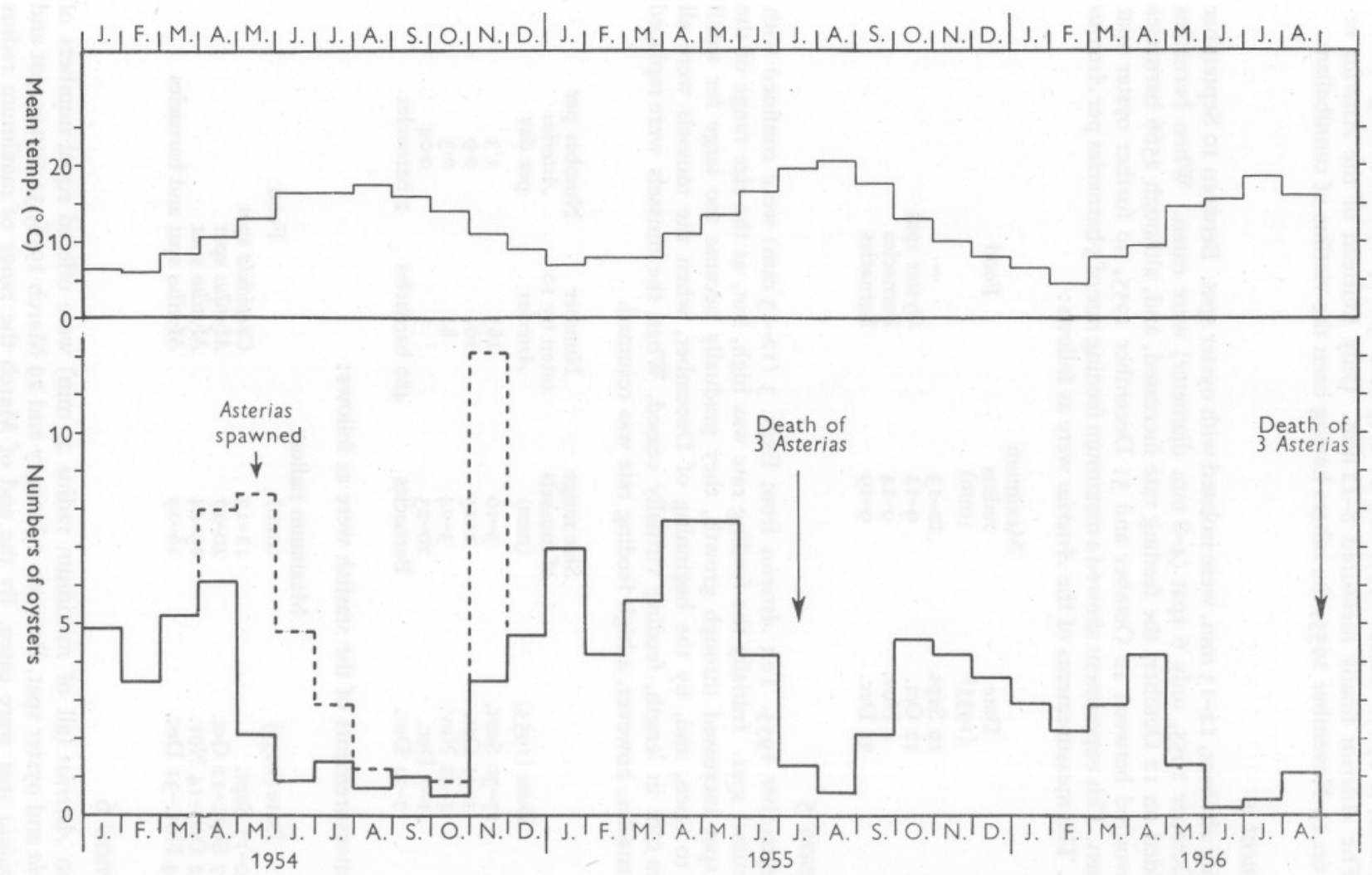

Fig. 4. Average numbers of adult oysters eaten per week by four large Asterias during each month from January I954 to August 1956. From April to November 1954, Crepidula were offered as an alternative, and the numbers eaten in addition to oysters have been shown by a broken line. Mean monthly temperatures are also given. 


\section{Experiment 7}

Five Asterias (maximum radius $20-30 \mathrm{~mm}$ ) were confined with roughly equal quantities of barnacles and mussel spat. Between 26 September and 22 October 1956, 665 barnacles and 293 mussels were eaten; between 23 October and 19 November a further 262 barnacles and 636 mussels. Mussel spat occur infrequently on the Southward Laying. This experiment may provide an instance of starfish attacking, at first, familiar food, and then turning their attention to an unfamiliar alternative, which they evidently liked. Alternatively, food habits may change with growth.

\section{Experiment 8}

On Io September 1955 a medium-sized Solaster (3I mm maximum radius) was confined with 20 Asterias (14-15 mm) and no other food. The Solaster needed from Io September to I2 November 1955 to devour all the Asterias. During this time the size measurements of the starved Asterias decreased.

\section{Experiment 9}

On ro September 1955 two small Solaster (maximum radius, IO-I I mm) were isolated with 20 Asterias (IO-I I mm) and no other food. When this experiment was ended on I9 November, I2 Asterias. remained, though greatly decreased in size, and one Solaster had been eaten by the Asterias. The size-range of the starved Asterias decreased as follows: Io September, I0-II mm; I2 October, 8-II mm; I4 November, 6-10 $\mathrm{mm}$.

\section{Experiment Io}

The experiment described previously (Hancock, 1955, Expt. I, p. 317), in which four large adult Asterias (maximum radius $140 \mathrm{~mm}$ ) were fed on adult oysters, was continued to try to demonstrate changes in feeding rate at different times of the year. The results are shown in Fig. 4. They are slightly complicated by the addition of a number of Crepidula on 21 April 1954, and their removal on I3 November 1954. The numbers of Crepidula eaten are shown in Fig. 4, and can be seen to exceed the numbers of oysters eaten by the Asterias, even though the latter had been conditioned to feeding on oysters for several months. Spawning of the Asterias took place in the laboratory during May, and feeding reached a maximum in April-May of each year, but the rate dropped soon after spawning and reached a minimum in August during the period of highest water temperatures. Steady feeding took place throughout the winter, with a slight drop in feeding rate each February, usually corresponding with the lowest monthly average of mean daily temperatures. The optimum feeding temperature appears to be between 10 and $13^{\circ} \mathrm{C}$. and occurs in April-May; above this temperature the feeding rate declines. It must be remembered, however, that the lowered feeding rate after April-May may have been associated with post-spawning effects.

Galtsoff \& Loosanoff (1939) kept starfish (Asterias forbesi) in tanks in the United States, and found that during the pre-spawning period, from the end of May until July, at temperatures from II $\circ$ to $\mathrm{I} 4.5^{\circ} \mathrm{C}$., the majority were indifferent to food. Soon after the completion of spawning starfish became exceedingly voracious, and continued to be so until the onset of cold weather. With the vernal rise of temperature, starfish became more and more activated but ceased eating with the approach of the breeding period. 


\section{FIELD OBSERVATIONS}

Throughout the surveys of the Southward Laying, records were kept of observations of feeding by Asterias and Solaster. Asterias was only occasionally taken when feeding, but the food of Solaster, which can ingest most food without pre-digesting it, was more easily recorded. Asterias was observed on four occasions devouring an oyster, and sixteen times eating Crepidula. The records of the food of Solaster were: Asterias 64, Crepidula 9, Alcyonidium I5, Gibbula II, and the anemone Diadumene 7. The Solaster which were feeding on Asterias varied in size from I3 to $85 \mathrm{~mm}$ maximum radius, and it was not until late September 1955 that the incidence of feeding on Asterias became frequent, increasing to a maximum in March 1956. Before September Solaster was observed feeding mainly on other animals, this change no doubt being associated with the settlement of young Asterias on the offshore part of the Southward Laying inhabited by Solaster. Two Solaster ( 62 and $66 \mathrm{~mm}$ maximum radius) were found eating smaller ones of the same species. One Solaster of only $14 \mathrm{~mm}$ maximum radius was found to have enveloped a Gibbula of $10 \mathrm{~mm}$ shell diameter. Feeding on Alcyonidium was mostly confined to the summer months when this bryozoan was in the active phase. These results agree with the observations of Fulton (I895), who found arms of Asterias protruding from the mouths of many specimens of Solaster dredged on oyster beds in the Firth of Forth.

Adult Asterias taken in dredge hauls in the River Swale, Kent, in December 1956, were observed to be feeding both on adult mussels and Crepidula which existed together there in abundance.

\section{PRACTICAL CONSIDERATIONS}

The laboratory feeding experiments showed that young Asterias ate large numbers of barnacles and young mussels, on which they maintained a steady growth. Oyster spat and Crepidula spat were much less acceptable, and such a diet alone was inadequate for growth, with actual reduction in size often resulting. Subsequent growth of the prey under these conditions made it less liable to attack by Asterias. Smith (1940) found that the rate of growth of $A$. vulgaris in eastern Canada varied with the kind and abundance of food. Mussels provided a much more favourable food for growth than oysters.

The spatfall of oysters at the Southward Laying is rarely intense, and Urosalpinx regularly destroys nearly all those present (Hancock, I954), so that as juveniles the starfish would normally not be a serious problem there. In fact some benefit must have resulted from the activities of the Asterias in keeping down the barnacles, which are the most important competitors of settling oysters for space and food (Waugh \& Ansell, 1956). A study of the seasonal feeding rate of adult Asterias showed that the best time to inspect for damage to highly cultivated oyster grounds is in the spring of the year before 
the starfish spawn. There has been no fresh evidence that Asterias is a serious pest of oysters under the conditions obtaining in Essex rivers, and both in the laboratory and in nature the starfish have continued to feed preferentially on competitors of the oyster.

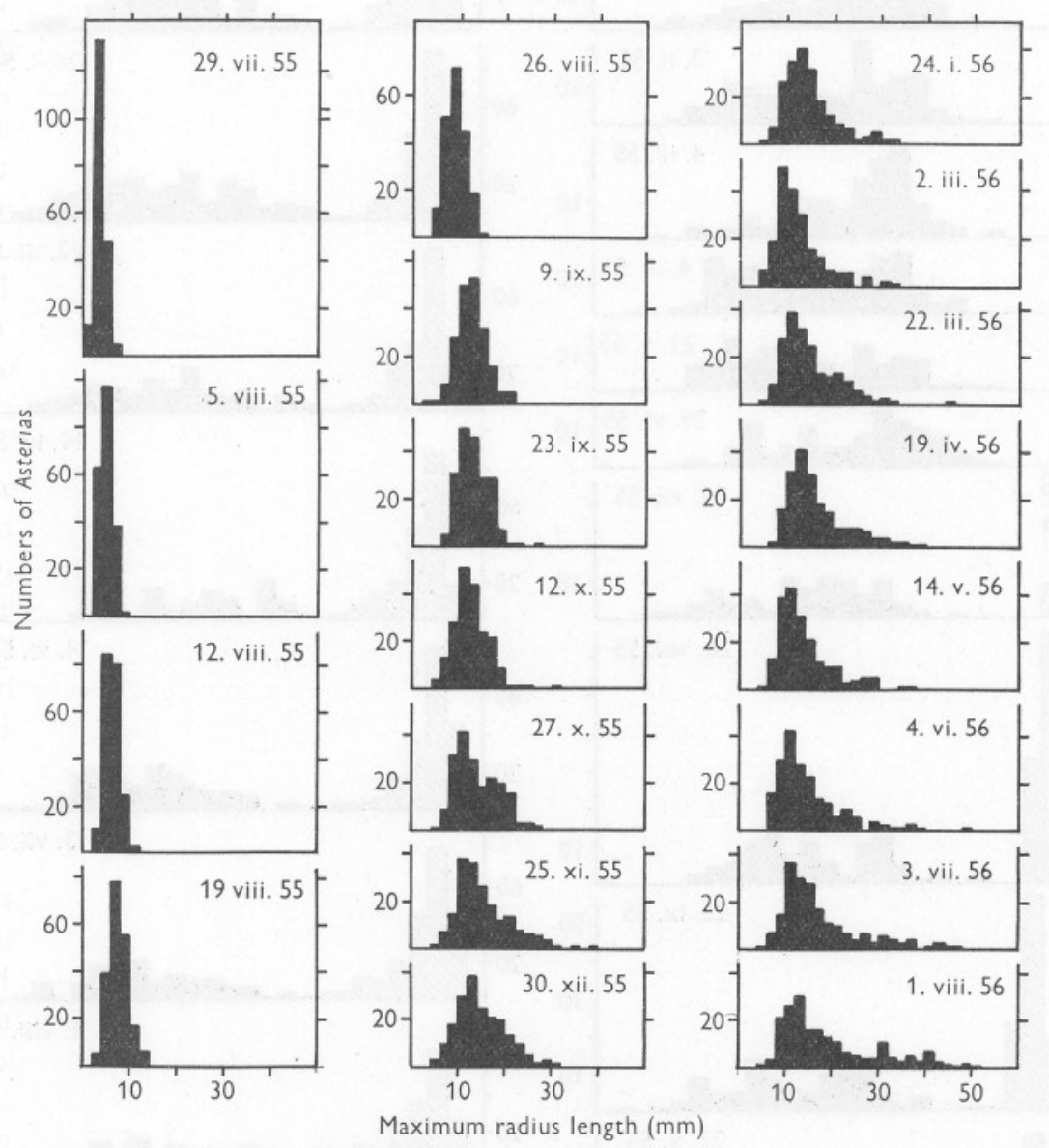

Fig. 5. Histograms showing the size distribution of young Asterias collected in dredge surveys from the Southward Laying $1955-56$. Each sample was composed of 200 individuals. The radius lengths have been grouped at $2 \mathrm{~mm}$ intervals.

\section{GROWTH}

The study of population histograms does not give a clear indication of growth under natural conditions unless (I) settlement of any year group takes place over a restricted period, and (2) a large number of the form being studied settle in a particular year, so that the progress of this year group can be traced 


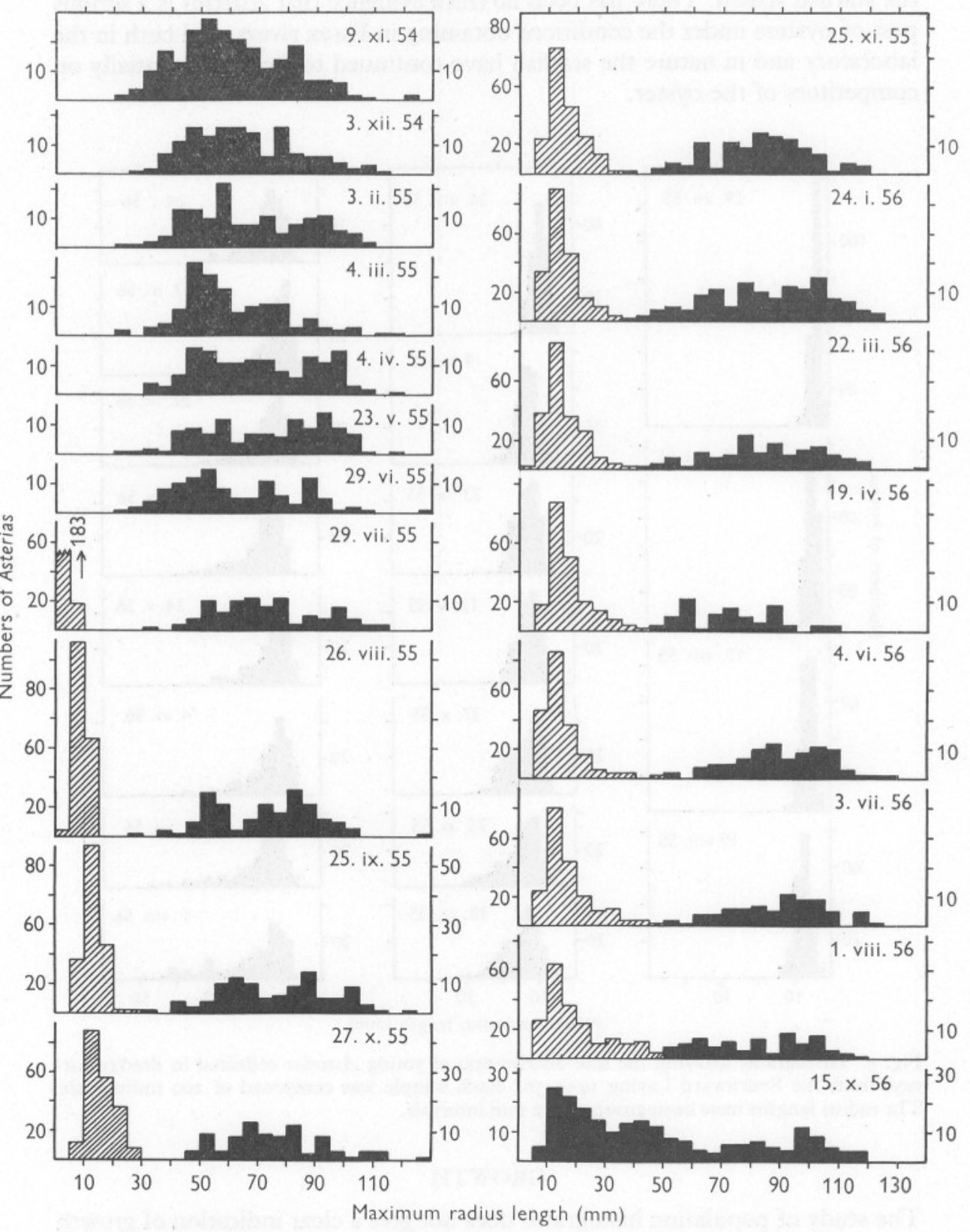

Fig. 6. Histograms showing the size distribution of young (shaded) and adult Asterias (blackened) collected in dredge surveys from the Southward Laying, 1954-56. Samples of 200 juveniles were measured, but all adult Asterias taken in the dredge surveys are shown. On 15 October 1956 all of both juveniles and adults taken were measured. The radius lengths have been grouped at $5 \mathrm{~mm}$ intervals, using different ordinate scales for adult and young starfish. 
in consecutive histograms. It was fortunate that heavy settlements of both Asterias and Solaster occurred in 1955.

Histograms have been plotted at intervals of $2 \mathrm{~mm}$ for measurements of the maximum radius of arm to show the growth within the 1955 year group (Figs. 5,7 ) and at $5 \mathrm{~mm}$ intervals to show the relationship of the year groups and their progress along the histograms (Figs. 6, 8). The Asterias population was sampled in two ways. First, the resident population was sampled,

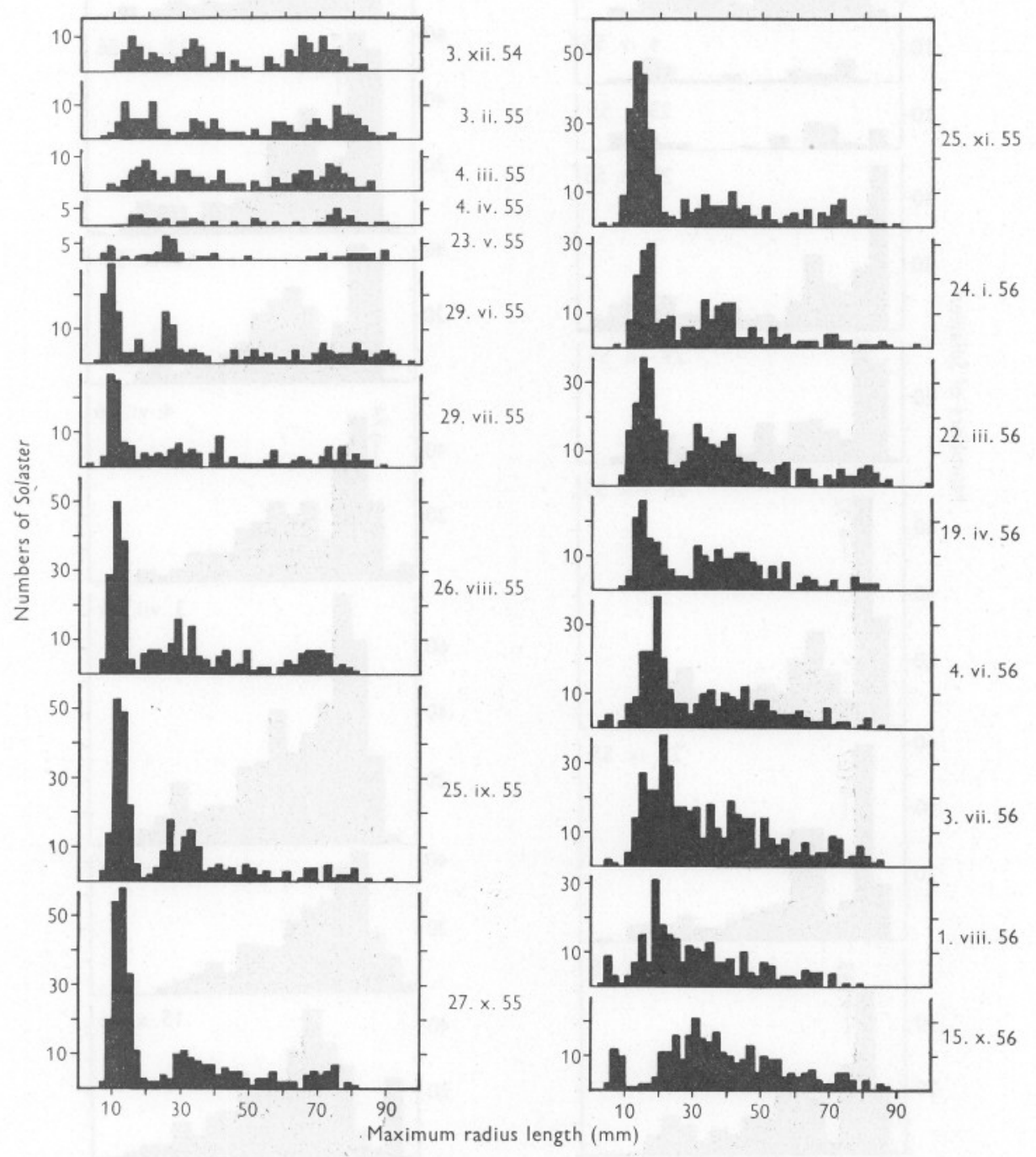

Fig. 7. Histograms showing the size distribution of Solaster collected in dredge surveys from the Southward Laying I954-56. The radius lengths have been grouped at $2 \mathrm{~mm}$ intervals. 


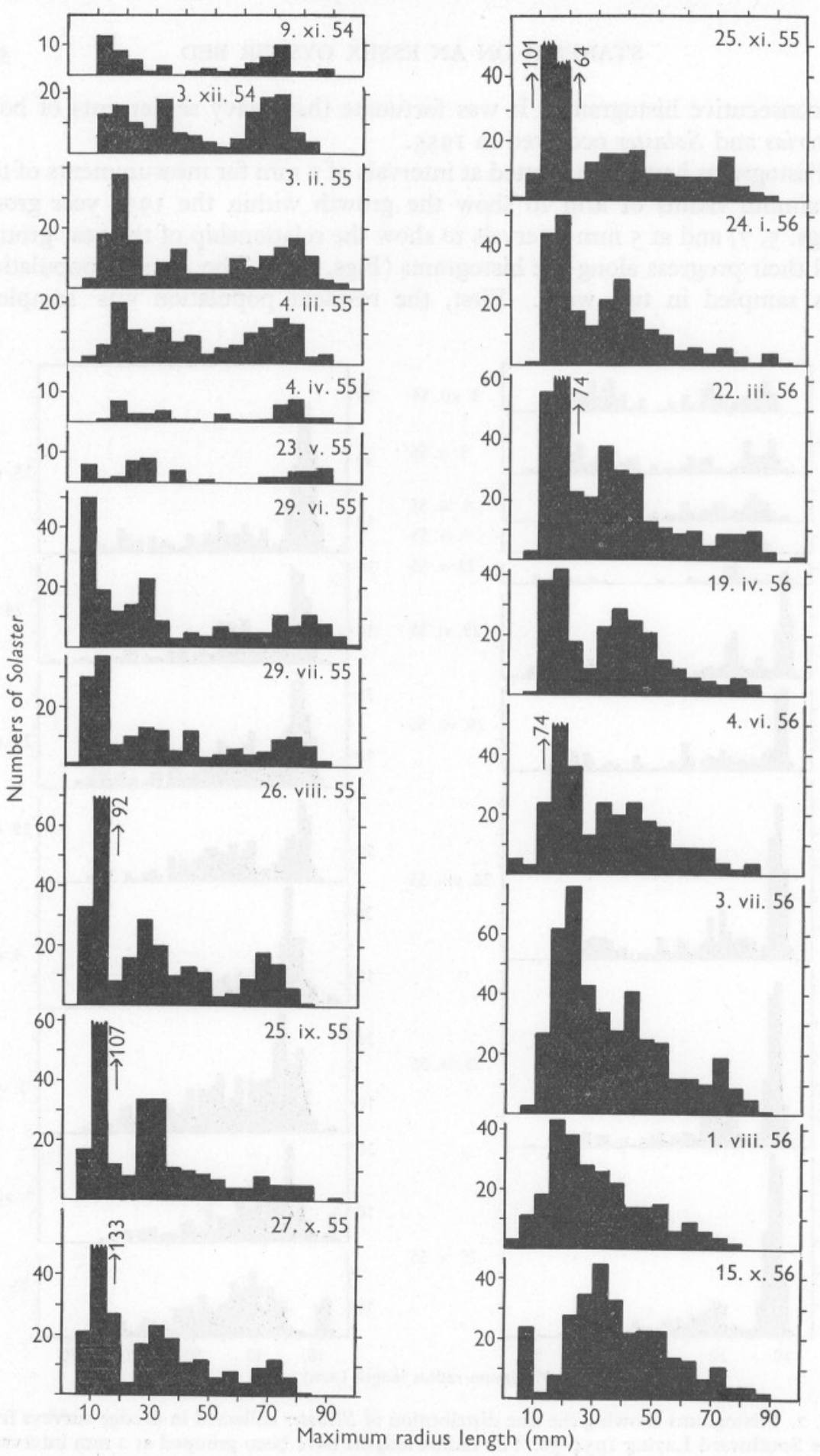

Fig. 8. Histograms showing the size distribution of Solaster collected in dredge surveys from the Southward Laying $1954-56$. The radius lengths have been grouped at $5 \mathrm{~mm}$ intervals. 
beginning on 9 November 1954, by measuring all Asterias collected in two dredge hauls over the stations examined on a particular date (Fig. 2). The settlement of I955 O-group individuals was first noted on 29 July I955, when the juveniles had a size range of $\mathrm{I}-7 \mathrm{~mm}$ and could readily be distinguished from the older year groups in the population. Measurement of all of the enormous quantity of juveniles collected was impracticable, so that although the remainder of the population was measured as before, only a randomly selected sample of o-group individuals from Station 2 was measured.

TABLE 3. GROWTH OF JUVENILE ASTERIAS AND SOLASTER AT SOUTHWARD LAYING, RIVER CROUCH

\begin{tabular}{|c|c|c|c|c|c|c|}
\hline \multirow[b]{2}{*}{$\begin{array}{l}\text { Date of } \\
\text { collection }\end{array}$} & \multicolumn{3}{|c|}{ Asterias } & \multicolumn{3}{|c|}{ Solaster } \\
\hline & $\begin{array}{l}\text { No. in } \\
\text { sample }\end{array}$ & $\begin{array}{l}\text { Mean length } \\
\text { of sample } \\
(\mathrm{mm})\end{array}$ & $\begin{array}{l}\text { Standard } \\
\text { error of } \\
\text { mean }\end{array}$ & $\begin{array}{l}\text { No. in } \\
\text { sample }\end{array}$ & $\begin{array}{l}\text { Mean length } \\
\text { of sample } \\
\text { (mm) }\end{array}$ & $\begin{array}{l}\text { Standard } \\
\text { error of } \\
\text { mean }\end{array}$ \\
\hline 29. vi.: 55 & - & - & 一 & 69 & $8 \cdot 5$ & 0.21 \\
\hline 29. vii. 55 & 200 & 2.9 & 0.08 & $7 \mathrm{I}$ & $10 \cdot 2$ & 0.29 \\
\hline 5. viii. 55 & 200 & $4 \cdot 3$ & $0 \cdot 10$ & - & - & - \\
\hline I2. viii. 55 & 200 & $5 \cdot 7$ & O.II & - & - & - \\
\hline 19. viii. 55 & 200 & $7 \cdot 0$ & 0.14 & - & 一 & - \\
\hline 26. viii. 55 & 200 & $8 \cdot 6$ & 0.15 & 127 & 10.7 & 0.16 \\
\hline 9. ix. 55 & 200 & $I 2 \cdot I$ & 0.22 & - & - & - \\
\hline 23. ix. 55 & 210 & $12 \cdot 2$ & 0.23 & - & - & - \\
\hline 25. ix. 55 & - & - & - & I49 & II $\cdot 8$ & 0.19 \\
\hline I2. X. 55 & 200 & I2:I & 0.27 & - & - & - \\
\hline 27. x. 55 & 200 & 15.4 & 0.33 & I84 & $12 \cdot 3$ & 0.18 \\
\hline 25. xi. 55 & 210 & 15.0 & 0.40 & I89 & 13.9 & 0.24 \\
\hline 30. xii. 55 & 200 & I 4.4 & 0.36 & - & - & - \\
\hline 24. i. 56 & 246 & $14 \cdot 2$ & 0.34 & II 4 & I5.8 & 0.33 \\
\hline 2. iii. 56 & $24 \mathrm{I}$ & II 8 & 0.32 & - & - & - \\
\hline 22. iii. 56 & 473 & $14 \cdot 3$ & 0.26 & 160 & $15 \cdot 8$ & 0.28 \\
\hline I9. iv. 56 & 278 & 15.9 & 0.38 & 105 & $16 \cdot 6$ & 0.40 \\
\hline I4. v: 56 & 253 & 13.2 & 0.35 & - & $\overline{0}$ & - \\
\hline 4. vi. 56 & 275 & I3. 8 & 0.39 & I49 & $\mathrm{I} 8 \cdot 2$ & 0.35 \\
\hline 3. vii. 56 & 215 & 16.6 & 0.57 & - & 一 & - \\
\hline I. viii. 56 & 216 & $19 \cdot 2$ & 0.72 & - & 一 & - \\
\hline
\end{tabular}

This sample was used to determine the standard error of the mean (Table 3). The measurements of only the first 200 individuals in each sample, however, were used for the comparative histograms (Figs. 5, 6). For this reason, in Fig. 6, the o-group is shown on a different scale from that of the main population and is distinctly shaded. In fact, the o-group Asterias represented a far larger proportion of the population than shown, and some idea of their density can be obtained by reference to Fig. 3. This method of subsampling was continued until I 5 October I956, when this year group had become so reduced that all the Asterias taken in the dredges could be measured. The numbers of young Solaster were never so great that they could not all be measured with the remainder of the population.

The mean size of each sample of 1955 o-group Asterias and Solaster (Table 3) has been plotted in fig. 9. Solaster showed a regular growth rate except between 24 January and 22 March 1956. The average growth between 


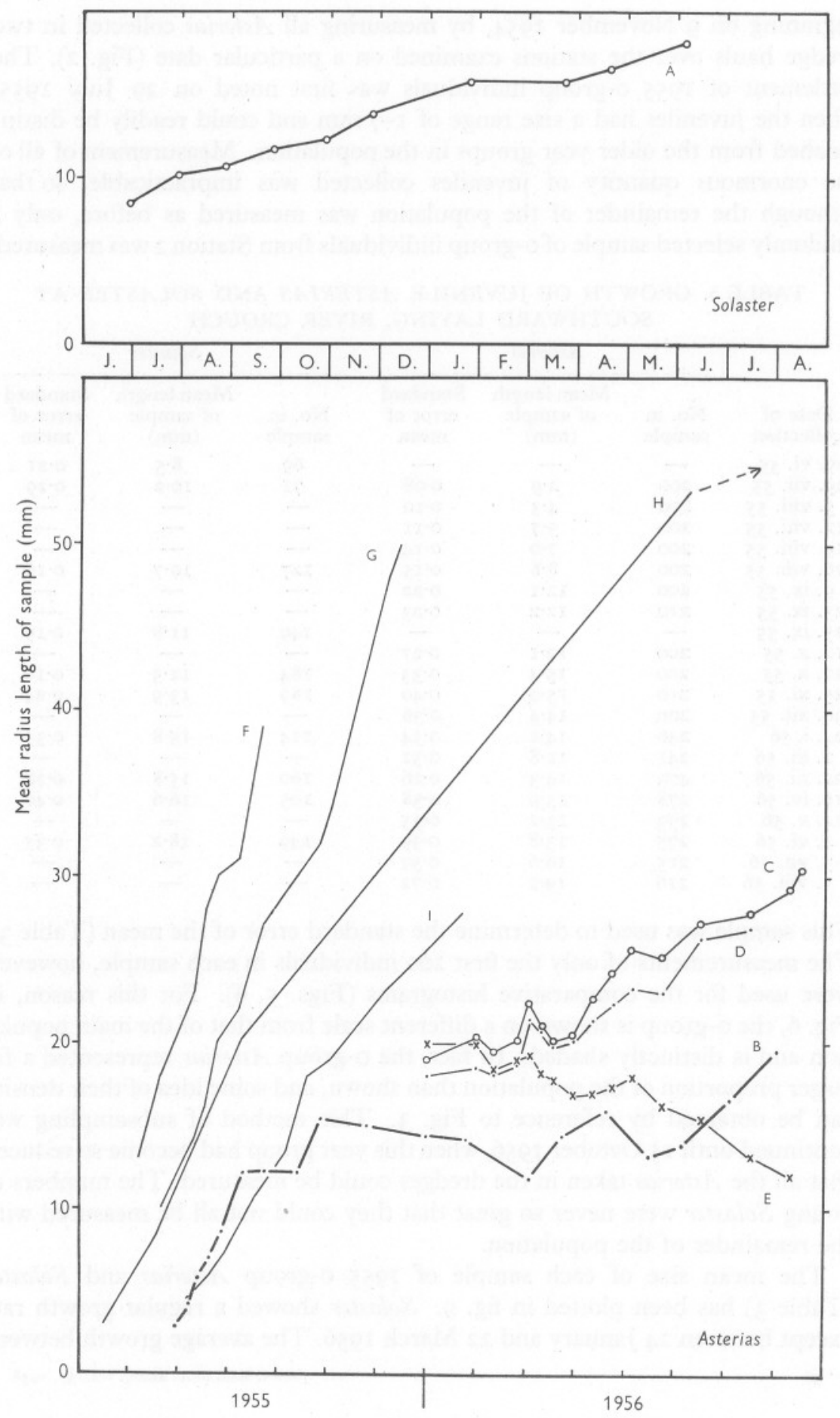

Fig. 9 
29 June 1955 and 4 June 1956 has been calculated as $0.028 \mathrm{~mm}$ per day, with a maximum rate of $0.056 \mathrm{~mm}$ per day between 27 October and 25 November 1955 .

A 1956 settlement of Solaster was first observed on 4 June, but the juveniles were less abundant than in 1955 , and on 15 October 1956 their mean size was only $6.8 \mathrm{~mm}$, compared with $12.3 \mathrm{~mm}$ for the 1955 o-group on 27 October 1955. This may have been due to a later settlement in 1956, or to the negligible crop of Asterias in 1956, whose young form the main food of Solaster. It is possible to trace the progression of the I954 o-group Solaster from November 1954. A comparison of the year groups on 3 February 1955 and 24 January 1956 (Fig. 8), shows the first two modes in a similar position, indicating that in 1954 and 1955 similar conditions of growth and settlement prevailed. On 4 June, when the 1956 settlement was first observed, the 1955 set of Solaster, at just over I year old, had a mean size of I8.I $\mathrm{mm}$ while the I954 set averaged about $40 \mathrm{~mm}$. From Fig. 8, it appears that in October the modes of the first few year groups are separated by regular intervals of about $20 \mathrm{~mm}$; they occurred at about $10,30-35,50$, and $70-75 \mathrm{~mm}$ respectively. Subsequent year groups were not clearly defined.

To state precisely the growth pattern of Asterias on the Southward Laying is more difficult. Newly settled juveniles were first detected in 1955 on 29 July at a mean radius of $2.9 \mathrm{~mm}$. Regular rapid growth, averaging $0.22 \mathrm{~mm}$ per day, was recorded until 9 September (mean radius $12.1 \mathrm{~mm}$ ), but then a check occurred. Mean size increased again between 12 and 27 October, but then decreased sharply until 2 March 1956. Reference to Fig. 5 shows that the decrease in mean size resulted from two processes; first, the range of size was increased by the slight growth of a small proportion of larger individuals, and, secondly, the mean size decreased. This is less surprising than may at first appear, in view of the shrinkage in radius length of starving Asterias noted in a previous section (see also Vevers, 1949). It is known that very small food organisms, e.g. barnacles, are necessary for the normal feeding and growth of young starfish. It is believed that the shortage of natural food was responsible for the enormous decline in numbers of young Asterias (Fig. 3) and for the reduction in the mean sizes of samples by actual shrinkage of individuals.

Growth of part of the juvenile population continued steadily from 2 March

\section{Legend to Fig. 9}

Fig. 9. Graphs showing the growth of young Asterias and Solaster. A: mean radius lengths of samples of young Solaster from the Southward Laying. B: mean radius lengths of samples of young Asterias from the Southward Laying (see Table 3). C-E: mean radius lengths of young Asterias kept well fed (C, D) and starved (E) in the laboratory (see Table 4). The results of other workers are given for comparison, showing the correct calendar months for their readings. F, G: radius lengths of two typical well-fed individuals of Asterias, B8 and B9, kept in the laboratory by Vevers (I949). H: average radius of the arms of an Asterias kept in the laboratory by Bull (I934). I: mean radius lengths of samples of Asterias from Millport measured by Barnes \& Powell (195I). 
to I9 April 1956, while the mode still remained at I0-I5 mm (Fig. 5). Then, after another setback in mean size, growth of juveniles continued to give the bimodal size-distribution shown for I 5 October 1956 in Fig. 6. The first mode, at IO-I5 mm, lies in exactly the same position as it was a year previously on 27 October I955. Unless one knew that 1956 settlement of Asterias had failed, the bimodal year group shown on the October 1956 histogram might be attributed to two normal year groups, instead of to the effect of abnormal growth conditions.

Bull (1934) showed that in three Asterias kept in the laboratory, first spawning occurred simultaneously when two were 5 years old and the third was 6 years old. Their average size was II $4 \mathrm{~mm}$. It seems unlikely therefore that the checks in growth observed during the first 2 years of the present observations were associated with spawning. Galtsoff \& Loosanoff (1939), however, found that in America young Asterias forbesi which grew rapidly were sexually mature by the end of the first year, whereas small, slowly growing animals did not mature until 2 years of age.

TABLE 4. GROWTH OF WELL-FED AND STARVED JUVENILE ASTERIAS IN THE LABORATORY

(12 Asterias in each group.)

\begin{tabular}{|c|c|c|c|c|c|c|}
\hline \multirow[b]{2}{*}{$\begin{array}{c}\text { Date of } \\
\text { measurement }\end{array}$} & \multicolumn{2}{|c|}{ Starved Asterias } & \multicolumn{4}{|c|}{ Well fed Asterias } \\
\hline & $\begin{array}{l}\text { Mean size } \\
\text { of group }\end{array}$ & Range & $\begin{array}{l}\text { Mean size } \\
\text { of group }\end{array}$ & Range & $\begin{array}{l}\text { Mean size } \\
\text { of group }\end{array}$ & Range \\
\hline I. i. 56 & 20 & 20 & I9 & I9 & I8 & I8 \\
\hline I. ii. 56 & 20 & $18-22$ & $20 \cdot 3$ & $18-26$ & 18.5 & $17-20$ \\
\hline II. ii. 56 & $18 \cdot 3$ & I6-2I & 19.5 & $17-25$ & $18 \cdot 2$ & I $7-20$ \\
\hline 25. ii. 56 & 19.0 & I6-22 & $20 \cdot 2$ & $18-25$ & I 8.8 & $17-23$ \\
\hline 3. iii. 56 & 19.3 & I6-2I & 22.4 & $20-25$ & $21 \cdot 5$ & $20-24$ \\
\hline Io. iii. 56 & $18 \cdot 2$ & I6-20 & $2 \mathrm{I} \cdot 0$ & $19-24$ & $20 \cdot 8$ & $17-23$ \\
\hline I7. iii. 56 & $17 \cdot 8$ & $15-19$ & $20 \cdot I$ & $18-24$ & 19.8 & $17-22$ \\
\hline 29. iii. 56 & I6.8 & I4-I9 & $20 \cdot 4$ & $19-22$ & $20 \cdot 2$ & $17-23$ \\
\hline II. iv. 56 & $17 \cdot 0$ & $14-19$ & $22 \cdot 7$ & $2 I-24^{\star}$ & $2 \mathrm{I} \cdot 4$ & I $5-25$ \\
\hline 23. iv. 56 & $17 \cdot 4$ & I6-I9* & $24 \cdot 3$ & $22-26$ & $22 \cdot 3$ & $19-26$ \\
\hline 5. v. 56 & $18 \cdot 0$ & $17-20$ & $25 \cdot 7$ & $23-27^{\star}$ & $23 \cdot 3$ & I $8-27$ \\
\hline 23. v. 56 & $16 \cdot 2$ & $15-18$ & $25 \cdot 2$ & $23-28$ & 23.0 & $20-28$ \\
\hline I6. vi. 56 & 15.5 & $13-18$ & $27 \cdot 3$ & $25-29$ & $26 \cdot 3$ & $2 \mathrm{I}-32^{\star}$ \\
\hline 16. vii. 56 & $13 \cdot 2$ & II-I 5 & $27 \cdot 8$ & $23-31$ & $26 \cdot 9$ & $2 \mathrm{I}-33_{\star}^{*}$ \\
\hline I0. viii. 56 & $12 \cdot 0$ & $\mathrm{II}-\mathrm{I} 4$ & $29 \cdot 3$ & $24-33$ & - & - \\
\hline I7. viii. 56 & - & - & 30.5 & $28-33$ & - & - \\
\hline
\end{tabular}

Experiments were set up to compare the growth of regularly fed and starved starfish. On I January 1956, a group of twelve $20 \mathrm{~mm}$ Asterias was confined with oyster and Crepidula spat; from previous experience, one would regard these as having virtually starved. Separate groups of twelve $19 \mathrm{~mm}$ and twelve $18 \mathrm{~mm}$ Asterias were confined with an excess of live barnacles. The starfish were measured regularly, along a selected radius, until July-August I956, when the original $20 \mathrm{~mm}$ group had reached II-I4 mm, the I9 mm 
group $28-33 \mathrm{~mm}$, and the $18 \mathrm{~mm}$. group $2 \mathrm{I}-33 \mathrm{~mm}$ (Table 4 ). The mean sizes of each group on the dates of measurement are shown in Fig. 9, and it is interesting to note that decreases in mean size were recorded, even for regularly fed Asterias, in February, March and May 1956. A sharp decrease, followed by an increase in size, was recorded in February among both the starved $20 \mathrm{~mm}$ Asterias in the laboratory and the natural population at the Southward Laying; this corresponded with the minimum water temperatures recorded in the winter of $1955-56$. The May decrease in mean size of well-fed laboratory individuals was evident in the Southward Laying population, and was also shown to a certain extent by a slightly accelerated decrease in the size of starved laboratory specimens. The author is indebted to $\mathrm{Mr} \mathrm{S}$. J. Holt of F.A.O., Rome, who, from an analysis of the growth data obtained from these experiments, was able to demonstrate the general consistency between observations from the field and the laboratory. He concluded that the concurrent rearing of two groups of animals, one fed at a predetermined level and one starved, is a useful method of studying growth parameters and their relation to environmental influences. The details of this analysis will be presented in a separate paper. In the natural population it appears therefore that the gradual decrease in mean size was due to starvation, and the final increase in mean size (I4 May-I August 1956) can be related to maximum summer settlement of barnacles in the presence of greatly depleted numbers of juvenile Asterias.

Bull (I934) reared three specimens of Asterias from newly settled young to sexual maturity in laboratory tanks at Cullercoats. He recorded the average radius, from the tip of the arm to the centre of the disc, of five arms, and obtained regular growth curves. The three starfish average $42 \mathrm{~mm}$ in the June after settling and II $4 \mathrm{~mm}$ at the time of first spawning. Vevers (I949) followed the growth of individual Asterias in the laboratory and Barnes \& Powell (195I) recorded a similar and quite rapid growth rate of young Asterias on a barnacle-covered raft at Millport. Graphs prepared from some of their figures are included in Fig. 9 for comparison with the present observations. The growth rate shown by the Southward Laying juveniles during the period soon after their settlement, and from June to August 1956, after reduction in numbers by competition had allowed the survivors to grow normally, was very similar to earlier records. Smith (I940) found that where high population densities of Asterias vulgaris Verrill occurred in eastern Canada, the size of individuals tended to be smaller. The growth of well fed individuals in our laboratory approached that found by Bull (1934) and Vevers (1949), but these also had been undersized for their age when transferred to laboratory tanks on I January I956. Orton \& Fraser (I930) examined a population of Asterias on a buoy near Liverpool: Vevers (I949) converted their measurements of diameter to radius sizes, and concluded that the Mersey population had grown considerably more slowly than the individuals in his laboratory experiments. 
The use of Nile Blue Sulphate for marking starfish in the field suggested an application for studying growth increments. Five Asterias from each group used to study growth in the laboratory were dyed with Nile Blue Sulphate. Their growth during the period in February-I7 August 1956 was not signicantly different from that of undyed starfish, indicating that dyeing did not interfere with their normal growth processes. Eventually white undyed tips were produced on the dyed radii, but the relationship between the undyed and total increments was somewhat variable. The following typical examples showed that up to half the total increment was undyed, suggesting, not very conclusively, that intercalary and terminal growth take place in equal proportions:

$\begin{array}{ccc}\begin{array}{c}\text { Original radius } \\ \text { length }(\mathrm{mm})\end{array} & \begin{array}{c}\text { Total increment } \\ (\mathrm{mm})\end{array} & \begin{array}{c}\text { Undyed increment } \\ (\mathrm{mm})\end{array} \\ \text { I9 } & \text { I2 } & 6 \\ \text { I9 } & \text { I2 } & 3 \\ \text { I9 } & \text { I0 } & 5 \\ \text { I8 } & 7 & 3 \\ \text { I8 } & 6 & 3\end{array}$

It is interesting to note that the stomach pouches of Solaster, which had eaten dyed Asterias, became coloured blue, giving a useful confirmation of their feeding behaviour.

\section{SUMMARY}

Observations on the distribution of adult starfish (Asterias rubens L. and Solaster papposus (L.)) on an oyster laying in the River Crouch have revealed no marked changes in their numbers or position throughout a period of nearly two years. Slight movement of Asterias was recorded, not inshore on to cultivated oyster ground but offshore to more derelict ground infested by slipper limpets (Crepidula fornicata Say). This offshore movement may have resulted from the clearing by dredging of large quantities of slipper limpets from the inshore region, necessitating a wider search for food by Asterias.

Young Asterias settled in 1955 in maximum density inshore on cultivated oyster ground, but some settlement also occurred farther offshore in the area inhabited by Solaster. Young Solaster settled mainly in mid-river in the region of greatest abundance of adults. Both young and adult Solaster have been observed devouring Asterias, particularly juveniles, while on a lesser scale Asterias may eat young Solaster. These facts, coupled with the discrete settling behaviour of Solaster are believed to be responsible for the very slight overlapping of the two adult populations.

The very dense population of Asterias which settled in 1955 on this oyster ground in the River Crouch has decreased steadily due to the combined effects of prolonged shortage of food, cannibalism and predation by Solaster. The dense population of barnacles formerly present on this ground has disappeared and none were seen in 1956. There was no settlement of Asterias in that year. 
Young Solaster showed a steady growth rate, but Asterias remained stunted until great reduction of the population allowed normal growth to be resumed. Feeding experiments showed that young Asterias grew well on barnacles and young mussels, which they ate readily, but young oysters and Crepidula were less acceptable and inadequate for normal growth.

\section{REFERENCES}

BAILEY, N. T. J., I95I. On estimating the size of mobile populations from recapture data. Biometrika, Vol. 38, pp. 293-306.

Barnes, H. \& Powell, H. T., I95I. The growth rate of juvenile Asterias rubens L. F. mar. biol. Ass. U.K., Vol. 30, pp. 381-5.

Bull, H. O., I934. Aquarium observations on the rate of growth and enemies of the Common Star-Fish, Asterias rubens L. Rep. Dove mar. Lab., Ser. 3, No. 2, pp. 60-3.

ChaDWick, H. C., I9I4. Echinoderm larvae. Mem. Lpool mar. biol. Comm., No. 22.

Cole, H. A. \& KNIGHT-Jones, E. W., I949. The setting behaviour of larvae of the European flat oyster. Fish. Invest., Lond., Ser. 2, Vol. I7, No. 3, pp. I-39.

Feder, H. M. I955. The use of vital stains in marking Pacific coast starfish. Calif. Fish Game, Vol. 4I, No. 3, pp. 245-6.

Fulton, J. W., I895. The past and present condition of the oyster beds in the Firth of Forth. Rep. Fish. Scot., No. 14, pp. 244-75.

GALTSOFF, P. S. \& LOOSANOFF, V. L., I939. Natural history and method of controlling the starfish (Asterias forbesi, Desor). Bull. U.S. Bur. Fish., Vol. 9, pp. 75-132.

Gemmill, J. F., I9I2. The development of the starfish Solaster endeca Forbes. Trans. zool. Soc. Lond., Vol. 20, No. I, pp. I-7I.

HANCOCK, D. A. 1954. The destruction of oyster spat by Urosalpinx cinerea (Say) on Essex oyster beds. F. Cons. int. Explor. Mer., Vol. 20, pp. 186-96.

— 1955. The feeding behaviour of starfish on Essex oyster beds. F. mar. biol. Ass. U.K., Vol. 34, pp. 313-31.

- (in press). The biology and control of the American whelk tingle, Urosalpinx cinerea (Say), on English oyster beds.

Knight-Jones, E. W. \& Stevenson, J. P., I950. Gregariousness during settlement in the barnacle Elminius modestus Darwin. F. mar. biol. Ass. U.K., Vol. 29, pp. 28I97.

Loosanoff, V. L., 1937. Use of Nile Blue Sulphate in marking starfish. Science, Vol. 85, p. 4I2.

— 1953. Tagging the 'Untaggable'. Progr. Fish Cult., Vol. 15, No. 4, pp. 186-7.

Orton, J. H. \& Fraser, J. H., I930. Rate of growth of the common starfish, Asterias rubens. Nature, Lond., Vol. I26, p. 567.

Shelbourne, J. E., 1957. The I95I oyster stock in the rivers Crouch and Roach, Essex, and the influence of water currents and scour on its distribution; with an account of comparative dredging experiments. Fish. Invest., Lond., Ser. 2, Vol. 2I, No. 2.

SмIтH, G. F. M., 1940. Factors limiting distribution and size in the starfish. F. Fish. Res. Bd Can., Vol. 5, pp. 84-103.

Vernon, A. A., I937. Starfish stains. Science, Vol. 86, p. 64.

VeVERS, H. G., I949. The biology of Asterias rubens L.; growth and reproduction. F. mar. biol. Ass. U.K., Vol. 28, pp. 165-87.

WAUGH, G. D. \& ANSELL, A., I956. The effect, on oyster spatfall, of controlling barnacle settlement with D.D.T. Ann. appl. Biol., Vol. 44, pp. 619-25. 